\title{
Magnetic and radiometric signatures of Creoulos and Córrego da Lavrinha tonian granitic intrusions and Anicuns-Santa Bárbara mafic-ultramafic Suite (Córrego Seco Body) in Anicuns, Goiás, Brazil
}

Davi Resende Messias $\left({ }^{*}\right)$, Lucas Portes Ramos, Marcelo Henrique Leão-Santos, Rodrigo Prudente de Melo, UNIVERSIDADE FEDERAL DE GOIÁS, FACULDADE DE CIÊNCIAS E TECNOLOGIA, Brasil

Copyright 2021, SBGf - Sociedade Brasileira de Geofísica

This paper was prepared for presentation during the $17^{\text {th }}$ International Congress of the Brazilian Geophysical Society held in Rio de Janeiro, Brazil, 16-19 August 2021.

Contents of this paper were reviewed by the Technical Committee of the $17^{\text {th }}$ International Congress of the Brazilian Geophysical Society and do not necessarily represent any position of the SBGf, its officers or members. Electronic reproduction or storage of any part of this paper for commercial purposes without the written consent of the Brazilian Geophysical Society is prohibited.

\section{Abstract}

The following research is related to airborne geophysics data processing and interpretation, in Anicuns west region, State of Goiás, Brazil. Its main goal is to interpret contacts, structures and lithologies, side by side with bibliography study, to give support to posterior geological mapping to be performed in the area. The results allow inferring geological structures, cinematic markers, magnetic and radiometric domains relations with geological units and allow a better understanding on the study area tectonic system. To achieve that, the data was checked by a quality control, interpolated with the bidimensional method and linear transformations were performed in order to generate the following magnetic products: Total Gradient, Vertical Derivative and Total Horizontal Gradient. The following radiometric products were interpolated: $\mathrm{K}, \mathrm{U}$ and $\mathrm{Th}$ channels, Total Count and ternary RGB-KThU Image. The data interpretation resulted in domains and lineaments detailed maps for magnetic and radiometric data. Finally, bibliography lithologies and structures mapped in the region could be correlated with magnetic and radiometric data and the geological units geophysical signatures were settled. As main results, the geophysical correlations between Goiás Magmatic Arc, metavolcanosedimentary sequence Anicuns-Itaberaí, Anicuns Santa Bárbara maficultramafic Suite (Córrego Seco body), and the granodioritic Creolos, the granitic Córrego da Lavrinha intrusions, were established with their magnetic and radiometric responses.

\section{Introduction}

The following research aims the use of geophysical airborne magnetic and radiometric data to apply interpretative techniques in an area to be geologically mapped. Our purpose is to perform data interpretation to generate a map that divides the area in domains with similar geophysical characteristics, correlated with the lithologies and structures in the study region.

The area is located in the central portion of Goiás State, specifically in the region of Anicuns city (Figure 1), where rocks from the Internal Zone of the Brasilia Belt, inside the Tocantins Province can be found. The regional geology is characterized as Proterozoic para and ortho-derivated metamorphic rocks and younger acid to basic intrusions, such as gabbros and granodiorites. Therefore, various geophysical signatures can be defined, as an example, the high magnetic susceptibility in mafic intrusions.

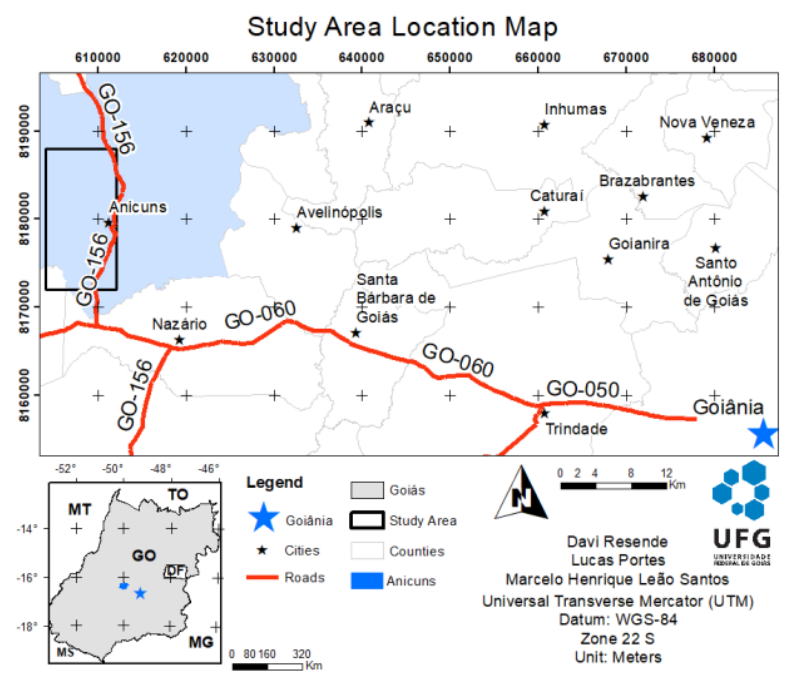

Figure 1: Study area location.

In order to proceed with the analysis, the first step was to process data, which included quality control, selection and application of the interpolation method and filtering the final data. To conclude the processing step, the magnetic transformed products and radiometric products were generated. Afterwards, the interpretation was performed, by defining the different domains that would indicate each lithology and the different lineaments that would trace the structures. To aid the correlation with the lithologies and structures in the area, geologic data from the previous mapping fulfilled by Meneghini and Carneiro (2020a and 2020b) and Martins and Santos (2019a and 2019b) were used.

\section{Method}

The work elaboration can be divided in two steps: the data processing and the qualitative interpretation, that led to the domains and lineaments interpreted maps correlated to known geology.

All geophysical data were obtained from the survey accomplished in 2004, by the partnership between CPRM (Brazilian Geology Service) and the Goiás Government through the Mining Promotion Fund (Funmineral). The first step was completely concluded using the software Oasis Montaj - Educational. To begin the processing, the coordinates DATUM was converted from SAD-69 to WGS84. After that, the quality control was conducted, in which the following was verified: the average flight height was $124 \mathrm{~m}$, the maximum was $275 \mathrm{~m}$ and the minimum was 75 
$\mathrm{m}$, while the contractual was $100 \mathrm{~m}$; the radiometric sampling has 80 to $90 \mathrm{~m}$ intervals, and the magnetic sampling has 8 to $9 \mathrm{~m}$ intervals along flight lines; the spacing between lines has small deviations and rarely exceeds 100 m over the 500 contractual line spacing; 24 dummies were found in the radiometric data, all in the Uranium channel. To determine data consistency, the fourth order difference was calculated. It helps on checking if there are inconsistent values, such as generated by the nugget effect. None was found. After assuring the data quality, the interpolation method was chosen. First, the cell size was selected. According to Vasconcelos et al. (1990) it should be between $1 / 4$ and $1 / 8$ of the spacing. As the line spacing in our case is of $500 \mathrm{~m}$, a 100-m cell size seemed to be the most proper. The methods compared were the Minimum Curvature and Bi-Directional, as suggested in Blum (1999) and Leão-Santos (2006). The figures used to compare them were the Total Magnetic Intensity (TMI) and the Total Gradient (TG), with shadowing declination at $90^{\circ}$ and shadowing inclination at $45^{\circ}$. In the TG figure generated by Minimum Curvature, an interference from the direction of the flight could be noticed, and that is why the Bi-Directional method was selected. It was also possible to check that this method filters less the data, when comparing the profile from both methods to the original values. After selecting the interpolation method, we applied a smoothing filter to remove any residual noise. The convolution filter was applied, which is a matrix statistic method. A comparison between the $3 \times 3$ and $5 \times 5$ symmetric convolutions applied once and twice showed that the last one eliminated the remaining flight direction trends, smoothed the noisy anomalies, and resulted in images with greater visual quality, without losing much data information.

Finally, the following radiometric data were plotted: Total Count (TC), Potassium in percentage ( $\mathrm{K} \%)$, Thorium in ppm (Th ppm), Uranium in ppm (U ppm), and ternary RGB - K Th U image (Figure 2.3). For the magnetic data, the following figures were plotted: the Total Magnetic Intensity (TMI), by interpolating the database; the Total Gradient (TG), using the Fast Fourier Transform (FFT) as derivative method in $X Y$ and $Z$ directions of magnetic measured field; the Vertical Derivative of first order (DZ1), by using the vertical derivative convolution filter (Figure 2.2); the Total Horizontal Gradient (THG), using the horizontal gradient filter with magnitude gradient; the Tilt Derivative (Tilt), in colour and shades of gray image distribution, also using the FFT as derivative in Z; and the two grid composition of TG and Tilt, by uniting the coloured TG image over the gray Tilt image (Figure 2.1). All figures and data processing were developed in Oasis Montaj software. The data interpretation, correlation and map layouts were done with ArcMap (Figures 2 and 3).

\section{Results}

The research results were the setting and characterization of the magnetic and radiometric domains and lineaments, as well as their correlations with the area known geology (Figures 3.1, 3.2 and 3.3).

\section{Magnetic domains interpretation}

Both the rocks and the anisotropies in the area might have magnetic signatures according to their mineral composition (such as magnetic minerals presence like magnetite), and contrasts are highlighted between places with different concentrations of the magnetic assemblages. Those contrasts are the key to define the lithologies and structures on the map, as an example, faults through where fluids may flow and raise the ferromagnetic minerals concentration. To define the magnetic domains (Figure 3.1 ), the most used figure was TG, as well as its intensity contours. The area was divided in four contrasting magnetic domains, that were compared to the regional geological maps, to correlate each domain to its lithology.

Magnetic Domain 1 (Figure 3.1, magenta colour):

Includes the majority of the central-north area, and is characterized by high magnetic amplitudes, greater than $0.3 \mathrm{nT} / \mathrm{m}$ values and a very rugged magnetic relief. When this signature is compared to geology, they are associated with the gabbros from the Complex Córrego Seco (CGDCS), which has in its composition high contents of magnetic minerals as magnetite.

Magnetic Domain 2 (Figure 3.1, red colour):

Occurs around domain 1, in the north and central north region of the area and in small areas at the south and east region. It is characterized by medium magnetic amplitudes, between 0.09 and $0.3 \mathrm{nT} / \mathrm{m}$, and a rugged magnetic relief as well. This signature is related to the diorites and amphibolites at the border of CGDCS at the north, and the small areas are related to basic-ultrabasic rocks from Anicuns_Itaberaí Sequence (SAI) and other unmapped features of the Goiás Magmatic Arc (AMG).

Magnetic Domain 3 (Figure 3.1, yellow colour):

Includes the south and southwest portion of the area and small portions in the northeast and northwest. It is characterized by a range of amplitudes from 0.015 to 0.09 $\mathrm{nT} / \mathrm{m}$, with intermediate magnetic relief. It is associated to orthogneisses of the Plutonic Complex from the AMG and to other psamo-pelitic rocks included in the SAI.

Magnetic Domain 4 (Figure 3.1, blue colour):

Is distributed as small areas in the southeast and west portions of the area, characterized by low magnetic amplitudes, lower than $0.015 \mathrm{nT} / \mathrm{m}$, with a low to very low magnetic relief (values as low as $0.006 \mathrm{nT} / \mathrm{m}$ ). It is related to the granodioritic intrusion Creoulos, and to other unmapped AMG features, that have low content of magnetic minerals.

\section{Magnetic lineaments Interpretation}

The magnetic method is an excellent lineament marker, and the lineaments are usually related to faults, fractures and shear zones. To delineate the lineaments, the most useful images were the coloured TG with the gray Tilt two grid composition (Figure 2.1) and the Tilt derivative.

Three major lineaments families were delineated: NE, E-W and NW. Most lineaments in NE direction are located in the AMG terrain and are related to the Transbrasiliano event, which inputs important ductile and transcurrent contributions and involves an important fracture and faulting control all over Goiás. Lineaments in E-W direction are interpreted as transcurrent shear zones, which crosscut intrusions and the basement rocks, and compressive shear zones, that are curved because of intrusion influence. The NW lineaments occur in the 
basement and are a result of faults and shear zones affecting or being affected by the NE structures, in two generation phases associated with Transbrasiliano event.

\section{Radiometric domains interpretation}

The $\mathrm{K}, \mathrm{U}$ and Th relative proportion obtained by gamma ray quantification is particularly useful in defining shallow lithologies. The radiometric interpretation delineated domains with different $\mathrm{K}, \mathrm{U}$ and Th proportions and set the domains relation with the mapped lithology units using contours for each radioisotope channel (Figure 3.2).

Three concentrations range were selected for $\mathrm{K}$ : low $(<0.3 \%)$; medium $(>0.3 \%$ and $<1.3 \%)$ and high $(>1.3 \%)$.

Three concentrations range were selected for $\mathrm{U}$ : low $(<0.015 \mathrm{ppm})$; medium $(>0.015$ and $<0.7 \mathrm{ppm})$; and high (>0.7ppm).

Five concentrations range were selected for Th: very low $(<0.67 \mathrm{ppm})$; low ( $>0.67$ and $<2.7 \mathrm{ppm})$; medium $(>2.7$ and $<4.5 \mathrm{ppm}$ ); high (>4.5 and $<6 \mathrm{ppm}$ ); and very high (>6ppm); because of the higher contrasts between concentrations.

Radiometric Domain I:

Occurs at the central north area and it is characterized by low $\mathrm{K}$, very low Th and low $\mathrm{U}$. The domain is associated to hornblend-gabbros, hornblend-norites and hornblendgabbronorites that belong to the CGDCS.

Radiometric Domain II:

Surrounds domain I, at central north portion of the area, and is characterized by low $\mathrm{K}$, Th and $\mathrm{U}$. The mapped rocks in domain II are related to the differentiated and metasomatized borders of the CGDCS, which include quartz-diorites, diorites, microdiorites and quartzamphibolites. The small Th enrichment is probably due to the magmatic differentiation, the fluids input, and the metasomatic interactions.

Radiometric Domain III:

Related to a local sigmoid in the northwest corner of the area, is characterized by medium $\mathrm{K}$ and $\mathrm{U}$ and low Th. It can be geologically related to the various metamorphic mafic-ultramafic rocks from SAI.

Radiometric Domain IV:

Defined as a small area at the central south portion of the area that has medium $\mathrm{K}$ and low to medium $\mathrm{U}$ and $\mathrm{Th}$. It is probably related to the metavolcanic basic-ultrabasic rocks from the SAI. The medium count in $\mathrm{K}$ (when comparing to domain $(X)$ is apparently related to drainage leaching in granites with high K (Córrego da Lavrinha Granite). The low $U$ and Th values open new perspectives for the domain, such as mafic-ultramafic intrusion from the CGDCS or other mafic-ultramafic unmapped conduits in the region.

\section{Radiometric Domain V:}

This domain is a south-eastern body characterized by high $\mathrm{U}$ and $\mathrm{K}$ and very high Th counts. It is represented by the Creoulos Granodiorite, that has an irregular, slightly rounded geometry. Its signature resembles the Lavrinha Granite (domain $\mathrm{VI}$ ), both have $\mathrm{K}$ high anomalies compared to porphyry feldspars, and Th and $U$ high anomalies from minerals as zircon and apatite. The intrusions differ in fractionation grade, Creoulos is a $S$ type granite more geochemically evolved and Lavrinha is an I type.

Radiometric Domain VI:

Occurs at the central southeast portion of the area and is characterized by high $\mathrm{K}, \mathrm{U}$ and Th counts. As stated, this represents the Córrego da Lavrinha granites, that contain microcline, plagioclase, biotite, and muscovite (Lacerda Filho et al. 1999), which are minerals with high K counts.

Radiometric Domain VII:

Includes a great portion at northeast part of the area, with medium K, Th and U counts. Geologically represents the meta-psamo-pelitic rocks from the SAI. The domain response have few count variations, due to the intercalations of sedimentary sequence.

Radiometric Domain VIII:

Located at northwest portion of the area and at a local body in the area center. The domain has low $\mathrm{K}$ and Th, and medium $U$ counts. At the north, it is associated to amphibolites and amphibole-schists of CGDCS intrusion border. The local body has compatible signatures with domain IV about a possible unmapped mafic-ultramafic intrusion.

Radiometric Domain IX:

This domain is located in the central south portion of the area and is characterized by low $\mathrm{K}$, and medium $\mathrm{U}$ and $\mathrm{Th}$ counts. It can be associated to amphibolites, amphiboleschists, and metavolcanic basic-ultrabasic rocks from the SAI. This domain indicate the contrast from the north-south tectonic suture with domain XII at east, related to the AMG.

Radiometric Domain X:

Located in the southeast corner of the area, characterized by medium $\mathrm{K}$ and high $\mathrm{Th}$ and $\mathrm{U}$ counts.

Radiometric Domain XI:

Referred to a body at west part of the area, characterized by medium $\mathrm{K}$, very high Th and high $\mathrm{U}$ counts.

Radiometric Domain XII:

Occurs at north-south region along the west portion of the area, characterized by high $\mathrm{K}$ and $\mathrm{U}$ and medium $\mathrm{Th}$.

The domains $\mathrm{X}, \mathrm{XI}$ e $\mathrm{XII}$ are, in the regional map, geologically related to the orthogneisses Unit of the Plutonic Complex in the AMG, but the distinct anomalies indicate that there is a possibility of a wide facies variety of gneissic rocks.

\section{Radiometric Lineaments Interpretation}

The radiometric method is useful to indicate outcropping lineaments, specially associated to lithologies contacts, and were mainly interpreted using the Total Count and the ternary RGB-KThU images. The lineaments were extracted, focused on aligned and linear features between anomalies domains (Figure 3.2). As the magnetic lineaments, there are three distinct lineament families: NE, $\mathrm{E}-\mathrm{W}$ and NW. The directions and geologic associations are the same as the magnetic interpreted structures. Although 
they can't show deep structures, the radiometric maps are better at defining the greater structures, such as the transcurrent and compressive shear zones with kilometric proportions.

\section{Conclusions}

The magnetic and radiometric responses interpretation allowed a detailed delimitation of the geology units and the structural elements, based on the domain and lineaments signatures characteristics. The use of geophysical data interpretation can support future field work to achieve a more precise and reliable detailed geological mapping.

The research results can be summarized as: the survey control quality evaluation, the data processing techniques application and the geophysical responses qualitative interpretation, including anomalous structures location, domains delimitation and geological correlations.

The Total Gradient associated to the Vertical Derivative, the Total Horizontal Gradient and Tilt Derivative, were efficient in defining the structures and the magnetic domains. The radiometric images from the $\mathrm{K} / \mathrm{Th} / \mathrm{U}$ spectrum, on the other hand, showed limitation to define deep structures, however precisely highlighted the kilometric shallow features, at the expense of the detailed aspects.

The radiometric data were efficient to delineate several radiometric domains with singular signatures tightly related to the units mapped in the regional geology map. The correlations between bibliography knowledge and the magnetic and radiometric interpreted products allowed the interpretation of structures cinematics, geological domains, and the region tectonic system better comprehension.

We can highlight, the Gabbro-Dioritic Complex Córrego Seco with magnetic anisotropies composition due to fractionation during crystallization and to the metasomatism occurred by fluids percolation. The complex was separated and detailed in different facies and lithotypes by using mostly the radiometric and also the magnetic contours. The evidence of unmapped smaller bodies was found, which are expected to be affirmed during future field work. Those zones delimitation are economically interesting due to their prospective potential.
The granodioritic Creolos and the granitic Córrego da Lavrinha intrusions are as well precisely definable, with high radiometric counts responses.

Besides that, the data processed and interpreted contribute to the previous knowledge on the study area apart from the previous geology mapping works, which allows the selection of interest points and improves the planning quality for future mapping.

\section{Aknowledgments}

We would like to thank CPRM and the Goiás Government, for allowing the use of airborne geophysical data.

\section{References}

Blum, M.L.B. 1999. Processamento e Interpretação de Dados de Geofísica Aérea no Brasil Central e sua aplicação à Geologia Regional e à Prospecção Mineral. Tese de Doutorado № 30, IG, Universidade de Brasília.

CPRM, 2004. Levantamento aerogeofísico do estado de Goiás, Relatório final do levantamento e processamento. Rio de Janeiro, Lasa Engenharia e Prospecções. $22 \mathrm{v}$.

Lacerda Filho, J.V. de., Rezende, A., and Silva, A. da, 1999. Geologia e Recursos Minerais do Estado de Goiás e Distrito Federal: Programa Levantamento Geológicos Básicos do Brasil, p. 200.

Leão-Santos, M.H. 2006. Processamento, nivelamento e integração de levantamentos aerogeofísicos magnetométricos no estado de Minas Gerais e sua contribuição à geologia da porção sul do Cráton São Francisco. Dissertação de Mestrado No 210, Universidade de Brasília.

Martins, F. R.; Santos, D. R. V. 2019ab. Carta Geológica, Folha Sanclerlândia (a) e Folha São Luís de Montes Belos (b). Escala 1:100.000. Goiânia: Serviço Geológico do Brasil - CPRM.

Meneghini, P. F. V. B.; Carneiro, J. S. M. 2020ab. Carta Geológica, Folha Itaberaí (a) e Folha Nazário (b). Escala 1:100.000. Goiânia: Serviço Geológico do Brasil - CPRM.

Vasconcelos, R.M.; Metelo, M.S.; Mota, A.C.; Gomes, R.D. 1990. Geofísica em levantamentos geológicos. Rio de Janeiro, DIGEOF-CPRM. 


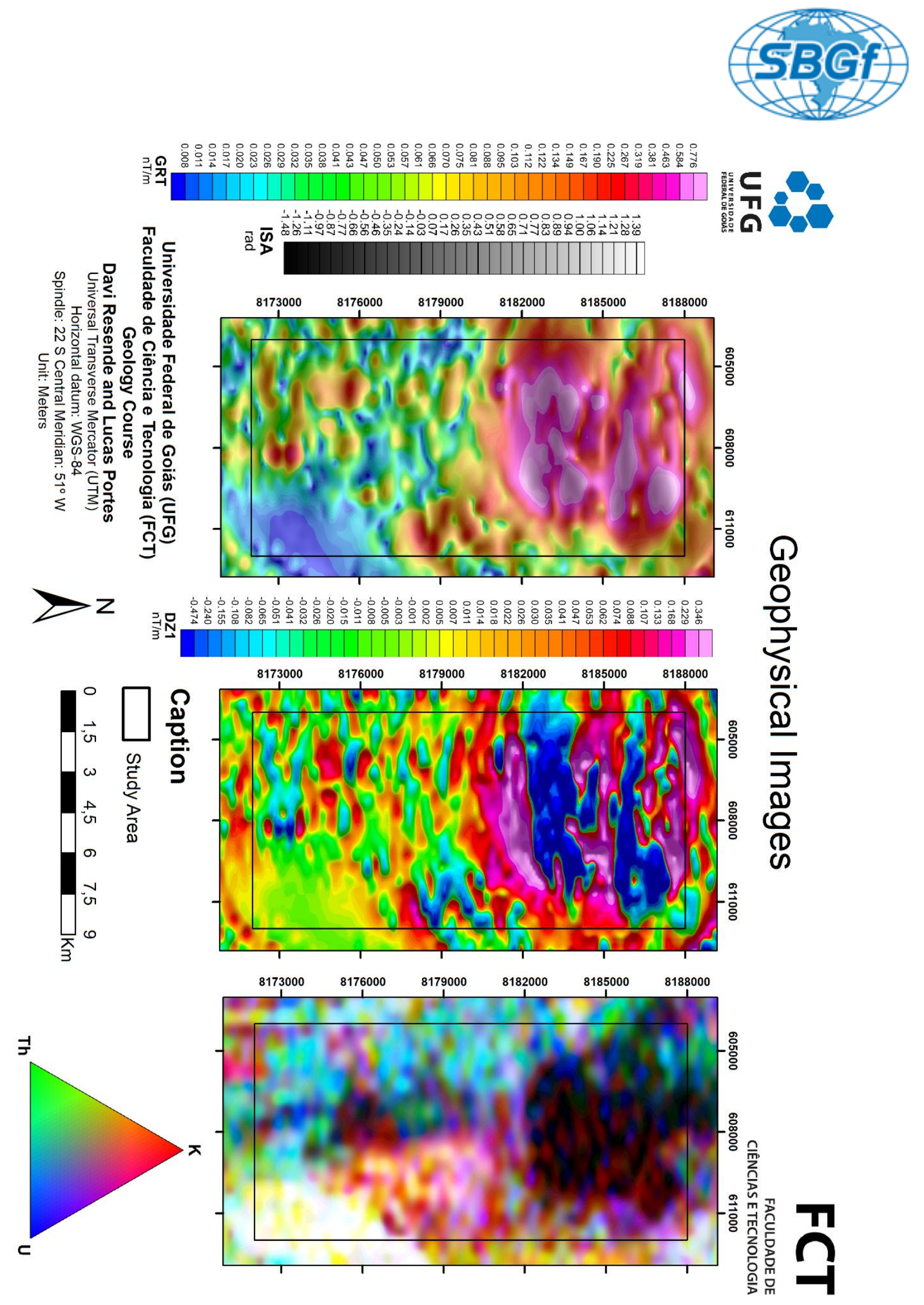

Figure 2 - Geophysics images.: 1) total gradient (colour) over tilt derivative (shades of gray) two grid composite, 2) vertical derivative and 3 ) ternary image RGB - K Th U. 


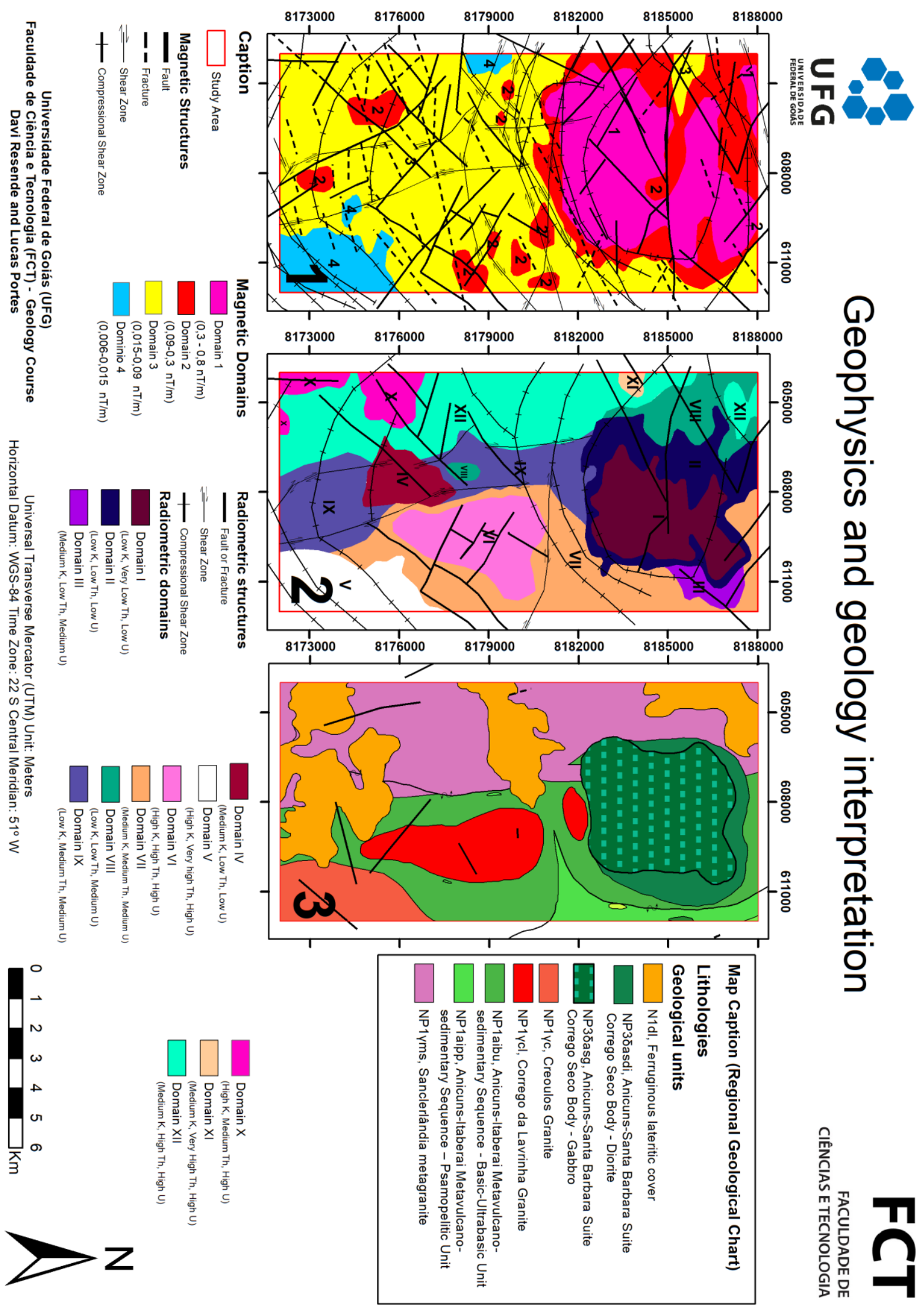

Figure 3 - Geophysics and geology interpretation and correlation: 1) magnetic lineaments and domains, 2) radiometric lineaments and domains and 3) known geology map (Martins \& Santos 2019ab and Meneghini \& Carneiro 2020ab). 